\title{
CARS Gene
}

National Cancer Institute

\section{Source}

National Cancer Institute. CARS Gene. NCI Thesaurus. Code C97369.

This gene is involved in transfer RNA metabolism. 